\title{
Preparing Accounting Graduates for Their Unpredictable Futures: The Insights from Accounting Graduates
}

Anis Suriati Ahmad, Zuriadah Ismail, Rohaila Yusuf, Noor Lela Ahmad and Nur Liana Ridzuan

To Link this Article: http://dx.doi.org/10.6007/IJARAFMS/v12-i1/11915 DOI:10.6007/IJARAFMS /v12-i1/11915

Received: 16 November 2021, Revised: 21 December 2021, Accepted: 30 December 2021

Published Online: 19 January 2022

In-Text Citation: (Ahmad et al., 2022)

To Cite this Article: Ahmad, A. S., Ismail, Z., Yusuf, R., Ahmad, N. L., \& Ridzuan, N. L. (2022). Preparing Accounting Graduates for Their Unpredictable Futures: The Insights from Accounting Graduates. International Journal of Academic Research in Accounting Finance and Management Sciences, 12(1), 88-97.

Copyright: (c) 2022 The Author(s)

Published by Human Resource Management Academic Research Society (www.hrmars.com)

This article is published under the Creative Commons Attribution (CC BY 4.0) license. Anyone may reproduce, distribute, translate and create derivative works of this article (for both commercial and non-commercial purposes), subject to full attribution to the original publication and authors. The full terms of this license may be seen

at: http://creativecommons.org/licences/by/4.0/legalcode

Vol. 12, No. 1, 2022, Pg. 88 - 97

http://hrmars.com/index.php/pages/detail/IJARAFMS

JOURNAL HOMEPAGE

Full Terms \& Conditions of access and use can be found at http://hrmars.com/index.php/pages/detail/publication-ethics 


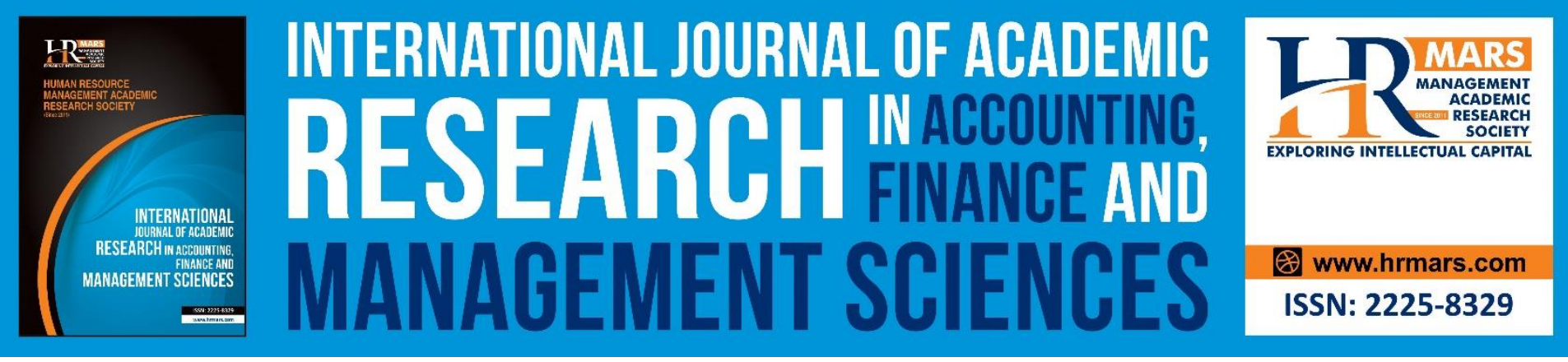

\title{
Preparing Accounting Graduates for Their Unpredictable Futures: The Insights from Accounting Graduates
}

\author{
Anis Suriati Ahmad, Zuriadah Ismail, Rohaila Yusuf, Noor Lela \\ Ahmad and Nur Liana Ridzuan \\ Faculty of Management and Economics, Universiti Pendidikan Sultan Idris (UPSI), \\ 35900 Tanjong Malim, Perak, Malaysia \\ Email: anis.suriati@fpe.upsi.edu.my
}

\begin{abstract}
In a rapidly evolving environment, the ability to anticipate and prepare for future skills requirements and knowledge is increasingly critical and challenging for higher education institutions around the world. A crucial question to be asked is regarding the appropriate set of skills and knowledge that should be embedded in the accounting curricula to prepare a future-ready accountant. Thus, this study examines knowledge and skills required by the accounting graduates at the time of entry to the profession. The questionnaire is used to solicit accounting graduates and students' viewpoint on the perceived knowledge and skills required by them at the time of entry to the profession. Descriptive statistic is employed to explain the finding of the study. Findings show that audit and investigation is perceived as the most important technical/knowledge competencies, whilst information technology is rated high in terms of professional skills. In regards to values, ethics and attitudes, trust and integrity are considered as the most important elements in the accounting profession. The outcome of this study serves as an important input for current and future accounting education, particularly to the accounting degree program in Malaysia.
\end{abstract}

Keywords: Accounting Education, Accounting Graduates, Accounting Students, Industrial Revolution, Knowledge, Skills

\section{Introduction}

The Fourth Industrial Revolution (4IR) or Internet of Things has the potential to transform jobs, tasks and skills required within industries over the coming years (White Paper, 2018).. It is defined as;

'... a new era that builds and extends the impact of digitisation in new and unanticipated ways... and can be described as the advent of "cyber-physical systems" involving entirely new capabilities and connectivity for people and machines.'

(Davis, 2016) 
MANAGEMENT SCIENCES

Vol. 12, No. 1, 2022, E-ISSN: 2225-8329 @ 2022 HRMARS

This suggests that the advancement in information technology and increased connectivity of social media networks will integrate businesses, facilities and machines across the value chain to share data in real time through cyber physical systems (CPS). This CPS will not only demand new capabilities and connectivity between people and machines but also transform the production, management and governance systems. This transformation is claimed to slowly replace human tasks and jobs which, subsequently changed on how employers or organisations look for the 'right talent'. Since the accounting tasks are grounded in data, knowledge and ability to capture, process, store, analyse, visualise and share data, necessary IT knowledge and social skills becomes crucial. Accountants need to embrace and adapt these technologies to stay relevant (Powell, 2017) as 'business as usual' is no longer possible for the accounting profession.

In this context, the accounting profession demand that accounting degree programs should integrate current and emerging accounting and business information technologies throughout the academic curricula in order to prepare accounting graduate for future workplace. There is a need to revisit the accounting curricula to address issues related to the course content, in order to meet the growing demands of the profession and the industry (Kiger, 2004; Norailis and Rozaini, 2015). The university should play significant roles in providing graduates with a comprehensive range of skills and should work closely with the accounting profession to bridge the expectation gap.

In such a rapidly evolving environment, the ability to anticipate and prepare for future skills requirements and knowledge is increasingly critical and challenging for higher education institutions around the world. Thus, to capitalise on aspects of $4 \mathrm{IR}$, the higher education institutions must embrace the pressure in ensuring the curricula offered is relevant to their graduates who may need to grapple with 4IR developments. In this context, higher education institutions must prepare students not only with the required knowledge and skills, but also with the aptitude to apply those skills throughout life (Heang et al., 2019). Surrounding by myriad technologies, an imperative question to be asked is regarding the appropriate set of skills and knowledge that should be embedded in the accounting curricula to prepare a futureready accountant.

While a number of studies have emphasized on the role and requirements of professional bodies (ACCA Report, 2016), or the insights from employers and practitioners about the skills and knowledge required by the accounting graduates at the time of entry to the profession (Zuriadah et. al, 2010), there are few studies that seek insights from the accounting students about their perceptions on this subject matter (Kavanagh and Drennan, 2008). A number of studies in higher education institutions in Malaysia have also suggested that accounting program is unable to meet the growing demands of the accounting profession (Azizi, 2001). Thus, this study aims to shed some valuable insights on the perceived knowledge and skills required by the accounting graduates at the time of entry to the profession from the accounting graduates viewpoints.

\section{Literature Review}

Accounting education has been extensively critiqued for failing to address the skills needed by the market and profession (Albrecht and Sack, 2000; Albrecht and Sack, 2001). In addition to conventional teaching method which often based on knowledge transmission and heavy 
MANAGEMENT SCIENCES

Vol. 12, No. 1, 2022, E-ISSN: 2225-8329 @ 2022 HRMARS

reliance on textbooks, scholars claim that the content of accounting education is narrowly focused on the technicalities of double-entry system and over emphasized on memorization of accounting procedures (Palm and Bisman, 2010). The emphasised on such technicaloriented knowledge is criticized for producing accounting graduates who are knowledgeable but lacking in terms of non-technical skills (Hill and Milner, 2006).

In addition, few studies suggest that the educational model has failed to respond to the everincreasing expectations of students entering the accounting profession (Kutluk et al., 2012). Some of the issues addressed in the literature are the lack of ICT knowledge and skills embedded in the accounting curricula, including the use of software (Ku Maisurah and Abrar, 2012). This has subsequently led to a gap between perceived knowledge and skills of accounting graduates with the industry or employer's expectations.

The higher education institutions are responsible in the initial professional development through the delivery of its accounting program, which has subsequently shaped the future of accountants. In response, the higher education institutions continuously review its accounting curricula and teaching methods to cope with the increased demand in the profession in order to enhance the employability of their accounting graduates (Jabbary and Madhoshi, 2014). The availability of educational technology and software can assist academicians in their teaching and learning activities (Erlane and Kamaruzzaman, 2019; Schuster et al., 2015) and provides opportunities to disseminate knowledge and engage with the students more effectively.

Nevertheless, Erlane and Kamaruzzaman (2019) highlights that the teaching and learning activities process can be more effective if the higher education institutions are able to bridge the expectation gaps, particularly in the era of $4 I R$. Thus, the profession and the industry should play subsequent role in providing continuing professional development for these accounting graduates through training and sponsoring of professional programs ( $O^{\prime}$ Connell et al., 2015). The increase demand from the profession and the advancement of technology have led to the expectations that accounting graduates should demonstrate additional competencies at the time of entry to the profession. Albrecht and Sack (2000: 55) highlight the importance of skill development of accounting students throughout their study at the higher education institutions and further emphasize that: "Students forget what they memorise. Content knowledge becomes dated and is often not transferable across different types of jobs. On the other hand critical skills rarely become obsolete and are usually transferable across assignments and careers".

The ACCA Report (2016) identifies technical and interpersonal skills and competencies required in several areas of accounting profession, including corporate reporting, taxation and the emerging ethical challenges. Some of the skills highlighted are critical thinking, problem solving, judgement, negotiation, cognitive flexibility and knowledge production. On the other hand, the International Education Standards (IES) Framework outlines five professional competence: (1) Technical Competence; (2) Professional Skills; (3) Professional Values, Ethics and Attitudes; (4) Practical Experience; and (5) Assessment of Professional Competence. 
MANAGEMENT SCIENCES

Vol. 12 , No. 1, 2022, E-ISSN: 2225-8329 @ 2022 HRMARS

\section{- Technical Competence}

Technical competence refers to professional knowledge, technical knowledge or technical accounting tasks (Guthrie, et al., 2014). It refers to the competencies that accounting students should develop throughout their study at the higher education institutions. Accounting students should be equipped with knowledge of concepts, standards, principles, facts, and procedures that enable them to be a competent professional accountant to meet an increasingly complex and changing environment. The IAESB has listed eleven (11) competency areas that need to be achieved at the end of the expected learning outcomes: Financial Accounting and Reporting, Management Accounting, Finance and Financial Management, Taxation, Audit and Assurance, Governance, Risk Management and Internal Control, Business Laws and Regulations, Information Technology, Business and Organizational Environment, Economics and Business Strategy and Management.

\section{- Professional Skills}

Generic skills refer to professional skills, transferable skills, soft skill or non-technical skills (Hall et al., 2013). These include interpersonal skills (communication, negotiation and teamwork), intellectual skills/appreciative skills (critical thinking), analytic skills (problem solving) and information and technology skills. In a rapidly changing landscape, scholars argue that accounting graduates should be well-equipped with these generic skills (Kavanagh and Drenan, 2008). This is in line with Pincus et al (2017) that highlight the need for changing skillsets which enable accounting graduates to organize, adapt, generate new skills and strategically apply their specific skills in new situations and circumstances especially in this rapidly changing industrial era.

\section{- Professional Values, Ethics and Attitudes}

Learning and development of professional values, ethics, and attitudes are always relevant due to change in the business landscape and increase exposure to a wide range of ethical issues (IAESB, 2015). The financial scandals and corporate malpractices have increased public concern regarding the ethical issues. This has led to the suggestion to enrich accounting curricula with the ethical subject to increase awareness about the ethical issues and moral obligations and subsequently, to restore the credibility of the accounting profession (McPhail, 2001). Lange et al (2006) contend that classroom exposure to ethical issues will increase students' ability to deal with the ethical dilemmas.

The IES specifies the five fundamental principles which include integrity, objectivity, professional competence and due care, confidentiality and professional behaviour. Besides, the IFAC provides a framework of professional values, ethics, and attitudes for aspiring professional accountants to exercise professional judgment and professional scepticism.

\section{- Practical Experience}

Adequate practical experience is needed to prepare accounting graduates for a real life working experience, which they unable to experience within the confines of the classroom (Warinda, 2013). D'Abate et al (2009) argue that the classroom environment unable to provide students with the complexities, problem analysis and solving involved in the real world. According to the IAESB, practical experience provides accounting students with an opportunity to develop their competencies and skills by understanding their working 
MANAGEMENT SCIENCES

Vol. 12, No. 1, 2022, E-ISSN: 2225-8329 @ 2022 HRMARS

environment and to develop responsibility and relationship under appropriate levels of supervision.

\section{- Assessment of Professional Competence}

According to IAESB, assessment is the measurement of professional competence developed through learning and development. It is a lifelong learning to develop and maintain professional competence and thus, professional accountant need to continue learning through Continuing Professional Development (CPD) program throughout their career. Changes in the working environment, career progress in or new roles may require professional accountant to increase their level of professional competence and acquire new set of competencies.

\section{Methodology}

Data of this study is collected using a questionnaire involving 42 accounting students from UPSI. The questionnaire is sent to these group of respondents through email. The questionnaire is developed based on a review of literature and various documents including accounting degree program offered by the Faculty of Management and Economics, UPSI and 'Hala Tuju 3 Program Perakaunan' (Accounting Program Direction Report for Malaysian higher education institutions). A reference also made to the Accounting Education Standards Board (IAESB) framework. In regards to the IES proposition, this study focuses on technical competence, professional skills and professional values, ethics and attitudes as these skills are gained whilst the students are still studying at the higher education institutions. Table 1 below shows the structure of the questionnaire.

Table 1: Structure of the Questionnaire

\begin{tabular}{|c|c|c|}
\hline Section & Component & $\begin{array}{c}\text { Total } \\
\text { Item }\end{array}$ \\
\hline A & Demographic Profile & 6 \\
\hline B & Technical Competence & 25 \\
\hline C & Professional Skills & 19 \\
\hline D & Values, Ethics and Attitudes & 6 \\
\hline E* $^{*}$ & Outcome and Professional Viewpoint & 3 \\
\hline
\end{tabular}

*For the purpose of this paper, Section E (open-ended questions) is not discussed.

\section{Discussion}

\section{- Knowledge and Skill Requirements of Accounting Graduates at the Time of Entry to the Profession}

The accounting graduates are asked to ranked their opinion about the required knowledge and skills needed at the point of entry to the profession. Table 2 shows that the graduates rated Audit and Investigation as the most important competencies needed, followed by Financial Management, Corporate Finance and Management Accounting. This finding revealed that auditing knowledge is compulsory as they need to be able to differentiate different types of audit and sources for audit evidences in order to come out with an effective audit work and report. Besides, the high rated items suggests that the accounting program in UPSI provides them with relevant knowledge needed at the time of entry to the profession. 
Table 2: Technical Competence

\begin{tabular}{llcc}
\hline No. & Subject of items & Mean (M) & $\begin{array}{c}\text { Standard } \\
\text { Deviation } \\
\text { (SD) }\end{array}$ \\
\hline 1 & Financial Accounting and Reporting & 3.74 & 0.812 \\
2 & Audit and Investigation & 3.90 & 0.870 \\
3 & Financial Management and Corporate Finance & 3.89 & 0.821 \\
4 & Taxation & 3.78 & 0.856 \\
5 & Management Accounting & 3.87 & 0.714 \\
\hline
\end{tabular}

In terms of professional skills, Table 3 shows that the accounting graduates rated information technology as the most important skill, followed by teamwork and problem solving. The high value of mean scored by each of the items in this category emphasized that all the six sets of professional skills studied in this research are equally important to equip accounting graduates with appropriate professional competency to meet challenges in an increasingly complex and changing business environment. In general, it can be inferred that these graduates are equipped with relevant professional skills whilst studying in UPSI. Mohamed and Lashine (2003) suggest that basic computer knowledge and other technological skills such as spreadsheet software, presentation and data base software, e-commerce, information systems planning and strategy and graphics software are required.

Table 3: Professional Skills

\begin{tabular}{llcc}
\hline No. & Skills of items & Mean (M) & $\begin{array}{c}\text { Standard } \\
\text { Deviation } \\
\text { (SD) }\end{array}$ \\
\hline 1 & Teamwork & 4.29 & 0.752 \\
2 & Negotiation & 4.10 & 0.744 \\
3 & Critical Thinking & 4.23 & 0.745 \\
4 & Problem Solving & 4.28 & 0.706 \\
5 & Communication & 4.14 & 0.770 \\
6 & Information Technology & 4.36 & 0.705 \\
\hline
\end{tabular}

The study further analyses the accounting graduate viewpoint with regards to Value, Ethics and Attitudes. Table 4 shows that the contents and delivery means of the subjects taken during their study in UPSI helps them to develop appropriate values, ethics and attitudes.

Table 4: Value, Ethics and Attitudes

\begin{tabular}{lllc}
\hline No. & Items Scale & Mean (M) & $\begin{array}{c}\text { Standard } \\
\text { Deviation } \\
\text { (SD) }\end{array}$ \\
\hline 1 & $\begin{array}{l}\text { I have the ability to be independent and take } \\
\text { immediate action without waiting for instructions. }\end{array}$ & 4.12 & 0.739 \\
\hline 2 & $\begin{array}{l}\text { I emphasize thoroughness in completing each } \\
\text { assignment. }\end{array}$ & 4.17 & 0.730 \\
\hline 3 & I am able to sort the tasks by priority. & 4.31 & 0.749 \\
\hline 4 & I believe duty is a trust that must be fulfilled. & 4.44 & 0.670 \\
\hline 5 & $\begin{array}{l}\text { I always practice behaviors that can serve as an } \\
\text { example by colleagues. }\end{array}$ & 4.40 & 0.701 \\
\hline 6 & I prepared quality work in a timely manner. & 4.36 & 0.727 \\
\hline
\end{tabular}


MANAGEMENT SCIENCES

Vol. 12, No. 1, 2022, E-ISSN: 2225-8329 @ 2022 HRMARS

\section{Conclusion}

The 4IR presents considerable challenges for nations worldwide, especially for higher education institutions who are preparing students for the jobs, of which some are seems to be diminished and some may be non-existent at present. Although adaptability becomes societal concern associated with 4IR, an imperative question to be asked regarding the mindset and willingness towards lifelong learning among students. This study provides valuable insights that can assist the Accounting and Finance Department, UPSI to constantly review and revise the structure of accounting programs to meet the industry demands. This is important to ensure appropriate set of skills and knowledge are embedded in the accounting curricula to prepare a future-ready accountant. As a number one education university, UPSI must exploit the potential opportunities that may arise from the development of 4IR with much responsibility and wisdom and creates an enabling environment for learners and academics to exploit opportunities offer by 4 IR.

Nevertheless, this requires a national commitment to transform accounting education. All related parties have to play their roles and responsibilities in bridging the gaps between theoretical basis and practicality. Future research may look into the awareness of accounting educators on 4IR and how the delivery of accounting education will be transformed. This is particularly relevance with the abundance of digital platforms and the burgeoning interests towards online learning due to Covid-19 pandemic.

\section{Acknowledgement}

This study was funded by a grant from UPSI. The research code: 2018-0226-107-01

\section{Reference}

ACCA. (2013). Big Data: Its Power and Perils. The Accountancy Futures Academy. www.accaglobal.com/futures.

ACCA. (2016). Professional Accountants - The Future: Drivers of Change and Future Skills. https://www.accaglobal.com/content/dam/membersbeta/docs/ea-patf-drivers-ofchange-and-future-skills.pdf

Albrecht, W. S., and Sack, R. J. (2000). Accounting Education: Changing the Course through a Perilous Future. Accounting Education Series (16). American Accounting Association, Saratosa.

Albrecht, W. S., and Sack, R. J. (2001). The Perilous Future of Accounting Education. The CPA Journal, 71 (3): 16-23.

Burritt, R., and Christ, K. (2016). Industry 4.0 and Environmental Accounting: A New Revolution? Asian Journal of Sustainability and Social Responsibility.

Davis, N. (2016). What is the Fourth Industrial Revolution? World Economic Forum Website. Retrieved online on 26 November 2018 at https://www.weforum.org/agenda/2016/01/what-is-the-fourth-industrial-revolution/.

Davies, R. (2015). Industry 4.0. Digitalisation for Productivity and Growth. Briefing for the European Parliament (PE 568.337), September 2015. European Parliamentary Research Service.

Dean, P. C., and Campbell, J. (2010). What Do Companies Expect of Accounting Majors. Review of Higher Education and Self-Learning, 3 (7):101. 
MANAGEMENT SCIENCES

Vol. 12, No. 1, 2022, E-ISSN: 2225-8329 ๔ 2022 HRMARS

Erlane, K. G., and Kamaruzzaman, M. (2019). Industry 4.0: Employers Expectations of Accounting Graduates and Its Implications on Teaching and Learning Practices. International Journal of Education and Practice, Conscientia Beam, 7 (1): 19-29.

Hall, R., Agarwal, R., and Green, R. (2013). The Future of Management Education in Australia: Challenges and Innovations. Education and Training, 55 (4/5): 348-369. https://doi.org/10.1108/00400911311326009

Heang, L. T., Ching, L. C., Mee, L. Y., and Huei, C. T. (2019). University Education and Employment Challenge: An Evaluation of Fresh Accounting Graduates in Malaysia. International Journal of Academic Research in Business and Social Sciences, 9 (9):106176.

Hill, W. Y., and Milner, M. M. (2006). The Placing of Skills in Accounting Degree Programmes in Higher Education. Some Contrasting Approaches in the UK. (Electronic Version), UK: Social Science Research Network.

IAESB. (2012). Continuing Professional Development (Redrafted). International Education Standard (IES) 7.

IAESB. (2012). Initial Professional Development - Assessment of Professional Competence (Revised). International Education Standard (IES) 6.

IAESB. (2012). Initial Professional Development - Professional Values, Ethics and Attitudes (Revised). International Education Standard (IES) 4.

IAESB. (2013). Initial Professional Development - Practical Experience (Revised). International Education Standard (IES) 5.

IAESB. (2014). Initial Professional Development - Professional Skills (Revised). International Education Standard (IES) 3.

IAESB. (2014). Initial Professional Development - Technical Competence (Revised). International Education Standard (IES) 2.

IAESB. (2014). Initial Professional Development [Brochure]. International Education Standard (IES).

IAESB. (2018). Proposed Revision to IESs 2, 3, 4 and 8 - Information and Communications Technologies and Professional Skepticism. International Education Standard (IESs).

Jabbary, N., and Madhoshi, M. (2014). Factors Affecting Knowledge Sharing Behavior in Academic Communities: Grounded Theory. International Journal of Education and Practice, 2 (6): 126-136.

Available at: https://doi.org/10.18488/journal.61/2014.2.6/61.6.126.136.

Kiger, C. E. (2004). Making Ethics a Pervasive Component of Accounting Education. Management Accounting Quaterly, 5: 1-18.

Kutluk, F. A., Donmez, A., Utku, B. D., and Erdogan, M. (2012). Expectation of Accounting Professionals from Accounting Education: An Antalya Research. Procedia-Social and Behavioral Sciences, 62:418-423. doi: 10.1016/j.sbspro.2012.09.068.

Ku Maisurah, K. A. and Abrar, H. (2012). Information Technology Competencies for Malaysian Accountants: An Academic's Perspective. ACIS 2012 Proceedings. https://aisel.aisnet.org/acis2012/55

Ku Maisurah, K. A., and Abrar, A. (2012). Information Technology Skills and Competencies: A Case for Professional Accountants. Lecture Notes in Business Information Processing, 127: 81-87. Doi: 10.1007/978-3-642-34228-8_9.

Lange, P. D., Jackling, B., and Gut, A. M. (2006). Accounting Graduates Perceptions of Skills Emphasis in Undergraduate Courses: An Investigation from Two Victorian Universities. Accounting and Finance, 46 (3): 365-386. Doi: 10.1111/j.1467-629X.2006.00173.x. 
MANAGEMENT SCIENCES

Vol. 12, No. 1, 2022, E-ISSN: 2225-8329 ๔ 2022 HRMARS

McPhail, K. (2001). The Other Objective of Ethics Education: Rehumanising the Accounting Profession: A Study of Ethics Education in Law, Engineering, Medicine and Accountancy. Journal of Business Ethics, 34 (3), 279-298.

Norailis and Rozaini, R. (2015). Critical Success Factor of Graduate Employability Programs. Journal of Economics, Business and Management, 3 (8): 767-771.

Azizi, N. (2001). The Importance of Non-Technical Skills in Accounting Graduates. Akauntan Nasional. Kuala Lumpur: MIA.

O'Connell, B., Carnegie, G., Carter, A., Helliar, C., Watty, K., Hancock, P., and DeLange, P. (2015). Shaping the Future of Accounting in Business Education in Australia.

Retrieved from:

http://www.cpaaustralia.com.au/professional-resources/education/global-researchperspectives-program/research-outcomes

Report number ISBN: 978-1-921742-67-5

Palm, C., and Bisman, J. (2010). Benchmarking Introductory Accounting Curricula: Experience from Australia. Accounting Education, 19:179-201. Doi: 10.1080/09639280903254959.

Pincus, K. V., Stout, D. E., Sorensen, J. E., and Stocks, K. D. (2017). Forces for Changes in Higher Education and Implications for the Accounting Academy. Journal of Accounting Education. Doi:10.1016/j.jaccedu.2017.06.001.

Powell, D. (2017). Global Brand Manager, IBM Cognitive Process Services \&amp; President, ACAUS. https://www.ifac.org/global-knowledge-gateway/

Schwab, K. (2016). The Fourth Industrial Revolution: What It Means, How to Respond. Retrieved online on 26 November 2018 at

https://www.weforum.org/agenda/2016/01/the-fourth-industrial-revolution-what-itmeans-and-how-to-respond/.

Sithole, S. (2015). Quality in Accounting Graduates: Employer Expectations of the Graduate Skills in the Bachelor of Accounting Degree. European Scientific Journal, 11: 165-180.

Seow, P. S., Gary, P., Goh, C., and Leong, K. S. (2017). Our Future Together Industry Perspectives: Future of Professional Learning and Entrepreneurship. Research Collection School of Accountancy; 1-43. Available at: http://ink.library.smu.edu.sg/soa_research/1561.

Warinda, T. (2013). Accounting Students' Evaluation of Internship Experiences from a Skills Perspective. International Journal of Asian Social Science, 3 (3): 783-799.

White Paper. (2018). Eight Futures of Work: Scenarios and their Implications. World Economic Forum.

Zuriadah, I., Suriati, A., and Aidi, A. (2020). Perceived Employability Skills of Accounting Graduates: The Insights from Employers. Ilkogretim Online - Elementary Education Online, 19 (4): 36-41. doi:10.17051/ilkonline.2020.04.104 